\title{
Quantification of water usage at a South African platinum processing plant
}

\author{
EL Haggard', CM Sheridan' ${ }^{1}$ and KG Harding ${ }^{1 *}$ \\ "Industrial and Mining Water Research Unit (IMWaRU), School of Chemical and Metallurgical Engineering, University of the Witwatersrand, \\ Johannesburg, Private Bag 3, Wits 2050, South Africa
}

\begin{abstract}
The mining industry utilises $3 \%$ of the total water withdrawn in South Africa and is one of the industries responsible for the deterioration of water quality in South Africa. Mine water requirements can be reduced with correct implementation and/ or improvement of current mine water management strategies. Any reduction in mine water requirements will reduce the demand on current water resources and hence the impact on water quality. The direct water footprint for 2 concentrators, a smelter and a tailings dam of a platinum processing plant were calculated using the Water Footprint Network assessment method. This includes the sum of the blue-, green- and grey-water footprints. Water footprints of chemicals used during flotation were excluded from the scope of the investigation. Water used in change houses and offices was included. The water footprint calculated from June 2012 until May 2013 was $201 \mathrm{~m}^{3} / \mathrm{kg}$ PGM (platinum group metals). The first concentrator had a water footprint of $76 \mathrm{~m}^{3} / \mathrm{kg}$ PGM, while the second had a water footprint of $110 \mathrm{~m}^{3} / \mathrm{kg}$ PGM. Overall, the total grey-water footprint made the largest contribution, accounting for $73 \%$, the blue-water footprint was the second largest (27\%), and there was no green-water footprint.
\end{abstract}

Keywords: Water in mining, blue water, green water, grey-water, footprinting

\section{INTRODUCTION}

In South Africa, mining plays an important role in the economy. In 2012, the mining industry generated $16.7 \%$ of South Africa's gross domestic product (GDP) and created 524632 direct jobs in the country (Chamber of Mines, 2013). Even though mining creates jobs and generates capital, it can have negative effects on the health and safety of mine workers and the environment.

Compared to other industries in South Africa, the mining industry does not consume that much water, as can be seen from Table 1. However the effect of mining activities on water quality can be severe. Contamination of water resources means that there is less water available for human consumption and

TABLE 1

Volume of water distributed to different industries in South Africa in 2010 (Stats SA, 2012)

\begin{tabular}{|l|c|}
\hline Type of customer & Volume $\left(\mathbf{m i l l i o n} \mathbf{~}^{\mathbf{3}}\right.$ ) \\
\hline Redistributors & 2310 \\
\hline Agricultural users (farmers) & 1969 \\
\hline Households & 308 \\
\hline Mining & 236 \\
\hline Industry & 119 \\
\hline Commercial users & 93 \\
\hline Total water distributed & 5035 \\
\hline
\end{tabular}

This paper was originally presented at the 2014 Water Institute of Southern Africa (WISA) Biennial Conference, Mbombela, 25-29 May 2014.

* To whom all correspondence should be addressed.

E-mail: kevin.harding@wits.ac.za environmental processes and that a large amount of capital has to be spent to clean up contaminated water

In the first global Water Disclosure Project initiated by the National Business Initiative, data from 8 South African companies were analysed. Of the 8 companies, 3 were mining companies. Seven of the companies $(88 \%)$ reported that they had experienced negative impacts related to water in the last 5 years (CDP, 2010). A reduction in mine water use is thus not only necessary to ensure clean water for human consumption and environmental processes, but will also help to ensure that future mine water requirements are met without placing additional burdens on available resources. A reduction in mine water use will also lessen the dependence of mining operations on water resources and reduce exposure to the effects of droughts.

In order to reduce water usage, an industry must first understand how water is used within its operations; from where it sources water, how much it uses, and what the return flows are and their quality. This information can also be benchmarked against other (similar or dissimilar) processes to compare a specific operation's water use in order to understand if the operation is utilising the resource efficiently. This can be done by calculating a water account for the process. A method that can be used is the Water Footprint Network (WFN) assessment method.

\section{The Water Footprint Network assessment method}

A water footprint is used to determine the volume of direct and indirect water utilised by an organisation in a process or to manufacture a product. The information gathered by calculating a water footprint can be used to assess the impact of a mining operation on the local environment and to identify strategies to reduce water requirements and thus the impact of mining operations on ground and surface water resources (Hoekstra et al., 2011). The information can also be used by 
policy makers, business leaders and regulators to create new water use and management strategies.

According to the latest WFN water footprint assessment manual (Hoekstra et al., 2011), the water footprint for any given stage of a process is the sum of its blue-, green- and grey-water footprints. The water footprint of a product is the sum of the water footprints for each processing stage in its production. Hoekstra et al (2011) define blue-, green- and grey-water footprints for a process as follows:

\section{Blue water}

The blue-water footprint of a process is the volume of ground and surface water that is consumed in the process. Consumption is defined as water that is not returned to the same water resource, or is not returned during the same time period (lost return flow), is lost through evaporation or is integrated into the product. Consumption is calculated as shown by Eq. (1).

$$
\begin{aligned}
W F_{\text {proc,blue }}= & \text { Blue Water Evaporation + Blue Water Incorporation } \\
& + \text { Lost Return Flow } \text { [volume/time] }
\end{aligned}
$$

\section{Green water}

The green-water footprint is the volume of rain water that is stored in or on the soil and used by plants for evapotranspiration. The green-water footprint is used in the forestry and agricultural sector (Tata, 2013). The green-water footprint can be calculated with Eq. (2).

$$
\begin{aligned}
W F_{\text {proc,green }}= & \text { Green Water Evaporation + Green Water } \\
& \text { Incorporation [volume/time] }
\end{aligned}
$$

\section{Grey-water}

The grey-water footprint for a process is the volume of clean water required to dilute pollutants in the wastewater to such an extent that the wastewater does not disturb the ambient water quality of the catchment into which it is released. The volume of clean water required is calculated with Eq. (3):

$$
W F_{\text {proc.grey }}=\frac{L}{C_{\max }-C_{n a t}}
$$

Where:

$L$ - pollutant load (mass/time)

$C_{\text {max }}$ - ambient water quality with respect to the pollutant (mass/volume)

$C_{\text {nat }}$ - natural concentration in the catchment (mass/ volume)

The grey-water footprint is calculated for every contaminant present in the waste stream. The total grey-water footprint is the water footprint for the contaminant with the largest greywater footprint. The grey-water footprint is included because it is assumed that the volume of water used to dilute the contaminants to the natural concentration of the water resource is not available for use by downstream users. The grey-water footprint is not a volume of water used by the operation but an indication of pollution caused by the operation.

\section{Applications of the WFN water assessment method}

The water footprint of a country was first defined by Hoekstra and Hung (2002) as the sum of the net virtual water of crops imported into a country and the volume of water used inside the country to produce the products consumed by the people in the country. Virtual water contained in a product is defined as the amount of water required to produce the product. Chapagain and Hoekstra (2004) calculated the water footprint of nations by calculating the volume of water used for crops, livestock, industrial processes and domestic use. Before the water footprint concept was introduced, the amount of water used by a country was defined as the amount of water used to produce products within the country. Chapagain and Hoekstra (2004) included both surface and groundwater (blue water) and precipitation (green water). To calculate the water footprints of countries, the water footprints of products have to be known. Chapagain et al. (2006) provide an example of calculating the water footprint for cotton. In this study, the effect of pollution on the local environment, caused by the process, is taken into account. It was defined as the volume of water required to dilute the water returned to surface and groundwater resources to such an extent that the concentration of the contaminants in the water resource remains below an agreed value.

The first industrial application of the water footprint method was done for 4 Tata companies located within India. The 4 companies are: Tata Steel, Tata Chemicals, Tata Motors and Tata Power. According to Tata (2013), the study that they conducted was the first industrial water footprint assessment. Water footprints were calculated for each process step in the production chain, and for each month. The aim was to determine which process step makes the largest contribution to water consumption and pollution, and to identify at which time of year most water is used and compare this to the volume of water available for use in the catchment. The same water footprint assessment procedures were followed for all 4 companies, but the report discusses Tata Steel in more detail. The discussion below was obtained from Tata (2013).

The Tata Steel operation that was studied is the Jamshedpur facility located in the Subarnarekha river basin. The grey-water footprint for the facility was calculated for 5 pollutants and 2 oxygen demand indicators. A grey-water footprint was calculated for each process step separately. This was done to identify the pollutant and the process step responsible for the grey-water footprint and show where more money and time has to be spent to reduce the grey-water footprint. Total suspended solids (TSS) were identified as the critical pollutant, and the steel making process made the largest contribution to the grey-water footprint. The process has 3 raw materials: iron, coal and lime. The water associated with the production of these 3 materials forms the indirect blue-water footprint for the operation. The greenwater footprint was defined as the volume of rain water that is stored in the soil and used for evapotranspiration by plants. The facility did not have a green-water footprint associated with production but the green-water footprint for the on-site horticulture at the facility was calculated.

For the sustainability assessment, other users of the water resource were identified and the amount of water used by each. The river, from which the operation received water, also provides drinking water to the local community and water to other industrial operations. Of the water withdrawn from the river, $30 \%$ was used by Tata Steel, $42 \%$ was supplied to the local community and $28 \%$ was used by other companies. According to the sustainability assessment, no water scarcity 
was experienced in the area at that time, but with an increase in water users the area could potentially experience water shortages during the dry months. Eight possible options were identified to reduce the water usage of the operation. Water footprint reduction cost curves were drawn to determine which of the 8 possible options would be financially feasible to implement. Viable options included recirculating more water, treating more water for reuse, measuring all intakes and discharges to track water usage, and replacing coke quenching with a new coke oven. Water response options also included water conservation options for the catchment in which the operation is located.

The water footprint of a base metal refinery located in South Africa was calculated by Osman et al. (2013). The blue-water footprint was defined as the volume of surface and groundwater consumed in the process. The base metal refinery had no grey-water footprint as no water from the site was released into a water resource. The green-water footprint was defined as the volume of rainwater consumed in the process. The bluewater footprint calculated was $33.4 \mathrm{~m}^{3} / \mathrm{t}$ of base metal product produced and the green-water footprint was $10.5 \mathrm{~m}^{3} / \mathrm{t}$ of basemetal product produced.

In a recent study, Ranchod et al. (2015) looked at the water footprint of an opencast platinum mine.

\section{Application of the WFN water assessment method to a South African platinum processing plant}

\section{Process and water flow description}

This investigation focuses on the water use of the 2 concentrator plants, the smelter and the tailings dam of a platinum mine. Different types of platinum ores have different gangue materials, and different grain sizes of precious metals and sulphides, and thus are processed in different concentrators, under different conditions (Liddell et al., 1986). Figure 1 shows a simplified water flow sheet for the concentrators, smelter and tailings dam. The process steps involved in platinum processing are: concentrating, smelting and converting, base metal recovery and precious metal recovery. For the site investigated, the concentrator process included crushing, milling, and flotation, followed by the cyclone and thickeners.

\section{Concentrator}

Platinum ore is transported from the mine to the processing plant by conveyor, road or rail. The ore is processed by crushing and milling to reduce the coarse ore to fine particles, liberating the sulphide-containing platinum group metals (PGM), iron, nickel and copper from the waste ore. This allows for easy separation during flotation (Crundwell et al., 2011). Water is added during milling to form a slurry, allowing for easy transportation of small particles and to adjust the density of the slurry for flotation. During flotation reagents are added to enhance the difference in the surface properties of the product and the waste material to increase separation during flotation. The top product, or concentrate, is rich in PGM and is thickened before being sent to smelting. The bottom product, the waste or tailings, is sent through a cyclone and thickener to remove water before being sent to the tailings dam. The water removed from the tailings can be returned to on-site water stores and reused in the process. The tailings dam is where most of the water is lost due to evaporation and seepage.

\section{Smelter and convertor}

In the smelter, 2 liquid phases are formed: a slag phase, which contains the oxide minerals or waste, and a matte phase, which



Figure 1

Simplified water flow sheet for the platinum processing plant 
contains the sulphide minerals or the product. The concentrate from the flotation is either flash dried or spray dried before being transferred to the furnace (Cramer, 2001). A moisture content of $5 \%$ is preferred before the smelter (Lidell et al., 1986). In the smelter, the water contained in the flotation concentrate is lost to the atmosphere as evaporation. Burnt lime or limestone is added to reduce the melting point of the slag and enhance separation in the furnace (Lidell et al., 1986). The slag from the furnace is granulated before being sent through milling and flotation to recover any PGM still contained in the slag (Cramer, 2001). The matte is sent through a converter. In the converter, iron (slag) and sulphur (gas) are removed from the product. The sulphur can be treated in a sulphuric acid plant. Converter slag can be sent back to the smelter to remove any PGM still contained in the slag (Lidell et al., 1986). The converter matte is cooled, crushed and noble metals removed by magnetic separation (Lidell et al., 1986)

This paper quantifies the volume of water consumed by a platinum mine, using the WFN assessment method. The use of water on the mine site and the effect of the mine on the local environment are discussed. Finally recommendations are made as to how to reduce the water required by a platinum mine.

\section{METHOD}

The method described by Hoekstra et al. (2011) was used to calculate the direct water footprint for the two concentrator plants, a smelter as well as the tailings dam of a platinum processing plant located in South Africa.

The steps involved in producing a water footprint assessment are:

1. Setting goals and scope

2. Water footprint accounting

3. Water footprint sustainability assessment

4. Water footprint response formulation.

\section{Setting goals and scope}

The purpose of this investigation was to determine which process in the operation used the most water and make suggestions as to how to reduce the volume of water required. Water footprints were calculated for 4 process steps: 2 concentrators, the smelter and the tailings dam. A previous study of the same processing plant only calculated the water footprint for 2 concentrators and the tailings dam (Haggard et al., 2013). The calculated water footprint is reported as the volume of water required to produce a kilogram of PGM contained in the converter matte that is sent off site for further processing. Blue-, green- and grey-water footprints were calculated for the mining operation, but only direct water footprints were calculated. Indirect water footprints were not included because information was not available for the water footprints of the chemicals and electricity used within the process. Water consumed in offices and hostels was included. The sewage generated on site is treated and used within the process. The water consumed in the treatment of the sewage was not included. The water footprint was calculated for 1 year of the operation from June 2012 to May 2013.

\section{Water footprint accounting}

Data obtained from the mining company included: metered inlet water flow rates, water flow rates between tasks, stores and treatment plants, surface areas and volumes of water stores, rainfall data, and fraction of water entrained in ore, product and gas streams. A list of tasks, stores and treatment plants was also provided. Average monthly evaporation data were obtained from literature (DWAF, 1985). Using this information a flow diagram was drawn and the unknown values were calculated based on design criteria and by closing the water mass balance. Blue and grey-water footprints were calculated and the process that requires the most water was identified. The critical pollutant responsible for the grey-water footprint was identified.

\section{Blue water}

The mine receives treated sewage from a nearby town. This water has been treated and thus can be used by other water users. It was assumed that this treated water can be released into a river system, but because the mine uses it, the water is not available for other users and it thus forms part of the blue-water footprint. In the water footprint previously calculated for this processing plant (Haggard et al., 2013), this water flow was not considered to form part of the blue-water footprint, because the water is not directly pumped from a ground or surface water resource. Other blue-water sources include potable water that is supplied by a water board. The water board withdraws the water from a surface water resource, the Vaal River. Borehole water is also withdrawn on the site. Water removed from mine shafts was not included because it forms part of the blue-water footprint for the mining operation, and the mining operation was not included in the investigation. For the same reason, water entrained in ore is not considered a blue-water source.

\section{Green water}

The operation does not have a green-water footprint because no garden is maintained on site. Previously, (Haggard et al., 2013), it was assumed that rain water and run-off water entering open water stores or catchment dams forms part of the green-water footprint. In this study, it is assumed that the rain water and run-off water forms part of the blue-water footprint, based on the green-water footprint definition used by Hoekstra et al. (2011). The total water footprint still remains the same.

\section{Grey water}

It was assumed that the only water returned to the source is the seepage from the tailings dam which is returned to an underground aquifer. The grey-water footprint was calculated by using the concentration of contaminants in the tailings dam rather than the concentration when it enters the aquifer. Water quality data were provided by the mining company. The maximum allowable concentration in the groundwater was taken to be equal to drinking water quality (DWAF, 2005) and the natural concentration was taken as the actual concentration of the water in the aquifer, and was obtained from the Department of Water Affairs and Forestry (DWAF, 2013).

Other assumptions include assuming that the mine closes down for 7 days during December and 3 days during Easter. There is a sewage treatment plant located on site that treats sewage generated from change houses, offices and hostels located on site. There were flow rate values available for water use in change houses and offices and for the concentrators and the smelter. It was assumed that the difference between the sewage generated on site and the treated sewage used on site was generated by the hostels. 


\section{Sustainability assessment}

Blue-water scarcity, as calculated by Hoekstra and Mekonnen (2011), was used during the sustainability assessment. The Hoekstra and Mekonnen study did not include the water scarcity of the surface water resource from which the mining operation receives its water, therefore the water scarcity levels of surface water resources located close by were used to give an estimate.

Blue-water scarcity is the ratio of the total calculated bluewater footprints in the catchment to the blue-water availability. The water availability is the water that is not required by the catchment ecosystem. If the water scarcity is $100 \%$, then all the blue water in the catchment has been consumed; if it is higher than $100 \%$, the environmental reserve is being used (Hoekstra et al., 2011).

\section{Water footprint response formulation}

In the final step of the water footprint assessment, recommendations are made as to how to reduce the water footprint impact on the local water resource, and reduce pollution.

\section{RESULTS AND DISCUSSION}

The total direct water footprint for the 2 concentrators, smelters and tailings dam was $743 \mathrm{~m}^{3} / \mathrm{kg}$ PGM and is shown in Fig. 2. The grey-water footprint made up 73\% (542 $\mathrm{m}^{3} / \mathrm{kg}$ PGM) of the total water footprint. The grey-water is caused by the seepage to an aquifer, from the tailings dam. The total blue-water footprint is $201 \mathrm{~m}^{3} / \mathrm{kg}$ PGM.

The distribution of the total water footprint between the process steps is shown in Fig. 3 as a pie/donut representation (Harding, 2013). The inner layer shows the total blue/grey while the outer layer gives the breakdown in each grouping. The tailings dam has the largest total-water footprint, $546 \mathrm{~m}^{3} / \mathrm{kg}$ PGM (74\% - grey-water plus blue-water impact). Concentrator 2 has the second-largest total water footprint, $110 \mathrm{~m}^{3} / \mathrm{kg}$ PGM (15\%). Concentrator 1 has the third-largest total water footprint, $76 \mathrm{~m}^{3} / \mathrm{kg}$ PGM (10\%), and the smelter has the smallest total water footprint, $11 \mathrm{~m}^{3} / \mathrm{kg}$ PGM (1\%).

The distribution of the blue-water footprint between the process steps is shown in Fig. 4. Concentrator 2 had the largest blue-water footprint, $110 \mathrm{~m}^{3} / \mathrm{kg}$ PGM (55\%). Concentrator 1 had the second-largest blue-water footprint, $76 \mathrm{~m}^{3} / \mathrm{kg}$ PGM (38\%). This indicates that Concentrator 1 operates more efficiently. The smelter had the third-largest blue-water footprint, $11 \mathrm{~m}^{3} / \mathrm{kg}$ PGM (5\%). The smallest blue-water footprint calculated is for the tailings dam, $4 \mathrm{~m}^{3} / \mathrm{kg}$ PGM (2\%). Rainwater entering the dam is the only contributor to the tailings dam's blue-water footprint.

Fig. 5 shows the 7 chemical contaminants that could cause a grey-water footprint. The critical component that is responsible for the grey-water footprint is magnesium. Magnesium and calcium enter the system with the ore as waste, and with groundwater.

The grey-water footprint is an estimation as the concentration values used to calculate the grey-water footprint are not the correct ones. For both concentrator plants there is no greywater footprint because water leaves the concentrator plants as evaporation or as process water to the smelter. The tailings dam has the only grey-water footprint, $542 \mathrm{~m}^{3} / \mathrm{kg}$ PGM, caused by seepage from the tailings dam into an underground aquifer.

Evaporation was calculated based on historical averages, not measured during the calculation time period. It is expected that water lost through evaporation should be slightly higher than calculated. The blue-water footprint calculated was $201 \mathrm{~m}^{3} / \mathrm{kg}$ PGM for the two concentrators, the smelter and the tailings dam, and does not include the mining step.

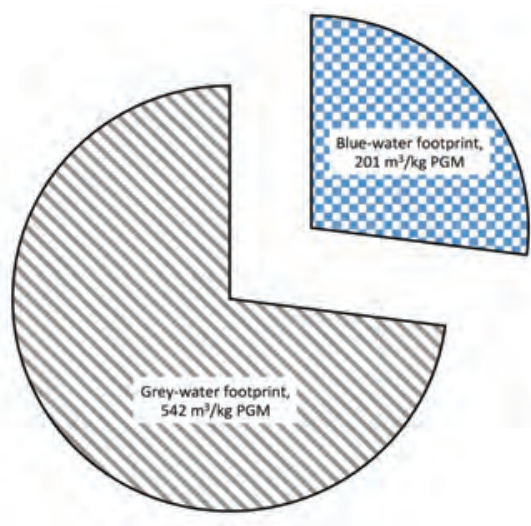

Figure 2

Total water footprint for platinum processing plant

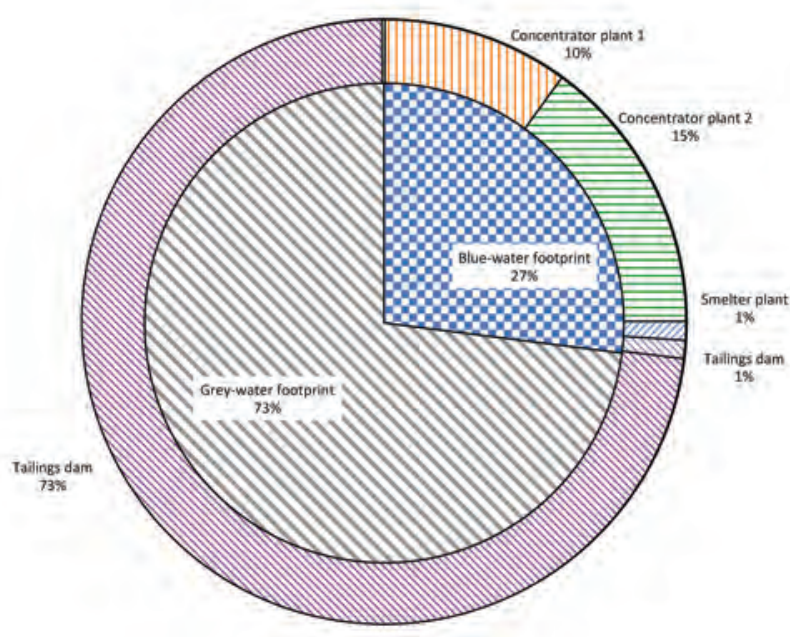

Figure 3

Distribution of total water footprint between the different process steps

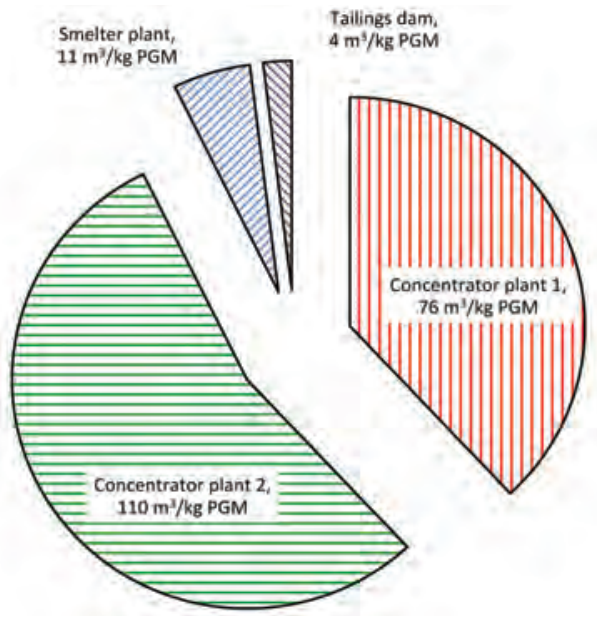

Figure 4

Distribution of blue-water footprint between the different process steps 
The water use values shown in Table 2 are for either a mine and concentrator $(\mathrm{MC})$ or for a mine, concentrator and smelter (MCS). None of the examples in Table 2 only include concentrator and smelter processes as was calculated during this investigation. It is expected that the calculated blue-water footprint for concentrator and smelter processes should be smaller than the water use calculated for MCS mines. The water use values in Table 2 for MC mines range from $192 \mathrm{~m}^{3} / \mathrm{kg}$ PGM to $1086 \mathrm{~m}^{3} /$ $\mathrm{kg}$ PGM. The calculated blue-water footprint falls within the range of water usage shown in Table 2.

The processing plant is supplied with water from the Vaal River through a water board. Blue-water scarcity values were calculated by Hoekstra and Mekonnen (2011) and are shown in Table 3. The Vaal River is not one of the rivers that was investigated, but all the South African rivers have at least 3 months of severe water scarcity during a year, indicating that the mine is located in a water-stressed country and that water usage has to be reduced. In reducing the volume of freshwater required by a mining process, the process will be less reliant on the water source and could potentially be less affected by water shortages during the water-stressed months.

Figure 6 shows the difference between rainfall and rate of evaporation for the processing plant. For all of the months the rate of evaporation is greater than the rainfall. By covering any open surfaces, water lost through evaporation will be reduced and less blue water is required to replenish the water stores. The tailings dam has a large open water surface and it is recommended that floating modules be used to cover the tailings dam (Marris et al., 2011). This will not completely prevent evaporation and rain water will still be able to enter. Due to the decrease in evaporation, more water will be available for recycling and the blue-water footprint can be reduced. If the water surface is covered, and it is assumed that evaporation can be decreased by $80 \%$, the blue-water footprint would be reduced by $0.3 \%$ to $195 \mathrm{~m}^{3} / \mathrm{kg}$ PGM and the total water footprint is reduced by $0.7 \%$ to $738 \mathrm{~m}^{3} / \mathrm{kg}$ PGM. The volume of blue water withdrawn was $9705 \mathrm{Ml} / \mathrm{yr}$. By covering the water surfaces the blue water could be reduced by $9.8 \%$ to $8753 \mathrm{Ml} / \mathrm{yr}$.



Figure 5

Grey-water footprint of contaminants in tailings dam

\begin{tabular}{|l|c|}
\hline \multicolumn{2}{|c|}{ TABLE 2 } \\
\hline Water use of PGM mine (Glaister et al., 2010) \\
\hline Individual/Mine & Water $\mathbf{~}^{\mathbf{3}} / \mathbf{k g}$ PGM \\
\hline Bafokeng-Rasimone (MC) & 235 \\
\hline Lebowa (MC) & 385 \\
\hline Potgietersrust (MC) & 277 \\
\hline Amandelbult (MC) & 209 \\
\hline Rustenburg (MC) & 229 \\
\hline Union (MC) & 237 \\
\hline Twickenham (MC) & 409 \\
\hline Mototolo JV (MC) & 192 \\
\hline Mimosa (MC) & 579 \\
\hline Manila (MC) & 582 \\
\hline Crocodile River (MC) & 1086 \\
\hline Northam (MCS) & 1612 \\
\hline Zimplats (MCS) & 606 \\
\hline
\end{tabular}


Other options include maintenance to prevent water loss through leaks in pipes or equipment. More flow meters can also be installed to make it easier to notice if there is a leak, or if a process step is not performing optimally. Educating workers on water saving measures and replacing current showers and toilets with water saving options could save further water.

\section{CONCLUSIONS}

This study has calculated the water footprint for 2 concentrator plants, a smelter and the tailings dam of a platinum processing plant in South Africa. The aim of the study was to identify areas in the processes where water use can be reduced. The direct water footprint was found to be $743 \mathrm{~m}^{3} / \mathrm{kg}$ PGM.

It was found that the tailings dam has the largest water footprint due to seepage and evaporation. The blue-water footprint made up $27 \%$ of the total water footprint.

A method that is recommended to reduce the amount of water required by the mineral processing stages involves covering any open water surface to reduce evaporation, especially the tailings dam which can be covered with floating modules. The volume of blue water required by the processing plant can be reduced by $9.8 \%$ to $8753 \mathrm{Ml} / \mathrm{yr}$.

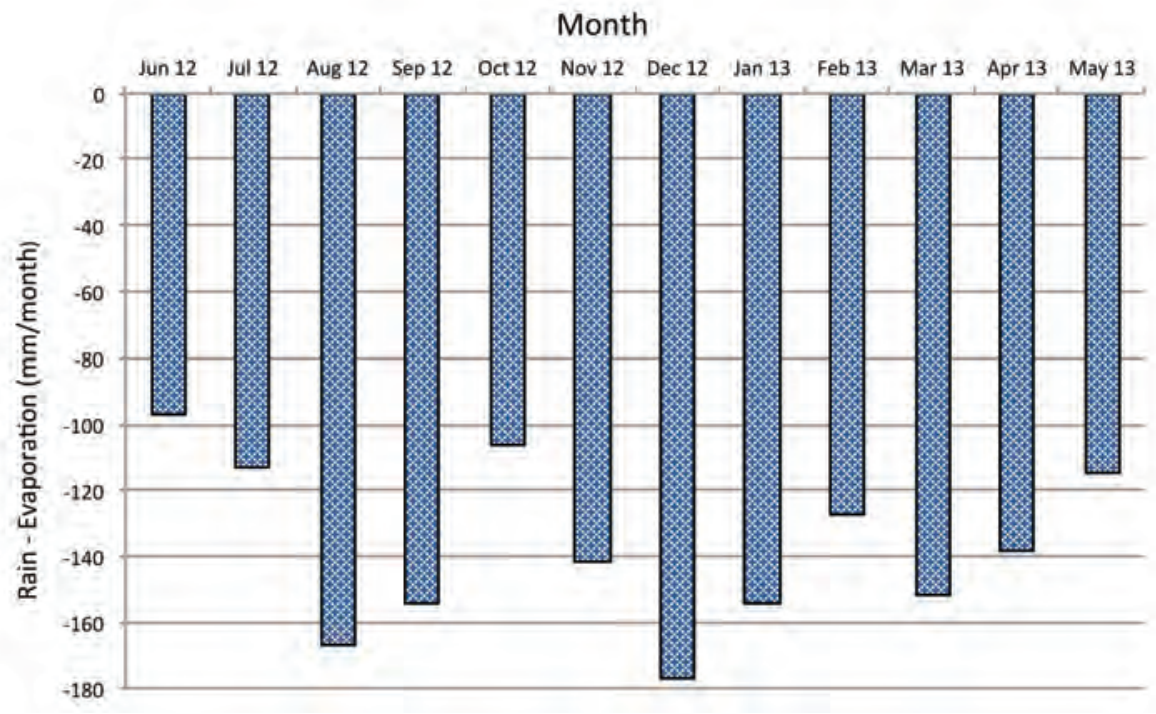

Figure 6

The amount of water loss due to the difference in the volume of rain received and evaporation rate

\begin{tabular}{|c|c|c|c|c|c|c|}
\hline \multicolumn{7}{|c|}{$\begin{array}{c}\text { TABLE } 3 \\
\text { Blue-water scarcity values for South African rivers (Hoekstra and Mekonnen, 2011) }\end{array}$} \\
\hline \multicolumn{2}{|l|}{ Basin name } & Limpopo & Orange & Tugela & Groot-Vis & Groot-Kei \\
\hline \multirow{13}{*}{ Water scarcity (\%) } & Jan & 26.29 & 32.86 & 8.46 & 675.67 & 454.09 \\
\hline & Feb & 20.30 & 49.71 & 20.53 & 675.68 & 456.33 \\
\hline & Mar & 39.17 & 53.49 & 34.31 & 675.68 & 204.97 \\
\hline & Apr & 74.61 & 61.90 & 42.82 & 675.68 & 192.07 \\
\hline & May & 78.33 & 51.60 & 43.91 & 675.68 & 285.75 \\
\hline & Jun & 125.22 & 101.67 & 71.94 & 675.68 & 377.99 \\
\hline & Jul & 211.34 & 186.01 & 142.38 & 675.68 & 490.53 \\
\hline & Aug & 374.09 & 305.73 & 257.90 & 675.68 & 575.44 \\
\hline & Sep & 491.64 & 382.79 & 341.08 & 675.68 & 628.27 \\
\hline & Oct & 526.77 & 324.39 & 321.52 & 675.68 & 648.28 \\
\hline & Nov & 454.14 & 135.20 & 148.45 & 675.67 & 611.61 \\
\hline & Dec & 146.56 & 62.55 & 17.71 & 675.68 & 569.38 \\
\hline & Average & 214.04 & 145.66 & 120.92 & 675.68 & 457.89 \\
\hline \multirow{4}{*}{$\begin{array}{l}\text { Number of months per } \\
\text { year that a basin faces } \\
\text { low, moderate, sig- } \\
\text { nificant or severe water } \\
\text { scarcity }\end{array}$} & Low $(<100 \%)$ & 5 & 6 & 7 & 0 & 0 \\
\hline & $\begin{array}{l}\text { Moderate } \\
(100-150 \%)\end{array}$ & 2 & 2 & 2 & 0 & 0 \\
\hline & $\begin{array}{l}\text { Significant } \\
(150-200 \%)\end{array}$ & 0 & 1 & 0 & 0 & 1 \\
\hline & Severe $(>200 \%)$ & 5 & 3 & 3 & 12 & 11 \\
\hline
\end{tabular}


By calculating the water footprint of their operations, mining companies can become aware of the amount of water that they use. Those processes where the most water is lost can be identified and steps can be taken to prevent the loss of water and reduce the amount of water used.

\section{ACKNOWLEDGEMENTS}

The authors wish to acknowledge funding from the South African Department of Science and Technology (DST) and the South African Minerals to Metals Research Institute (SAMMRI). We are also grateful for the support of the platinum company that provided the data.

\section{REFERENCES}

CDP (CARBON DISCLOSURE PROJECT) (2010) CDP Water Disclosure 2010 South Africa Focus. URL: http://www.nbi.org.za/ Lists/Publications/Attachments/95/CDP-Water-Disclosure-2010South-Africa.pdf (Accessed 8 January 2014).

CHAMBER OF MINES (2013) Facts about South African mining: Putting South Africa first. URL: http://www.bullion.org.za/content/?p id=138\&pagename=Mining+Fact+Sheet (Accessed 7 November 2013).

CHAPAGAIN AK and HOEKSTRA AY (2004) Water footprints of nations, value of water. Research report series No. 16. URL: http:// www.waterfootprint.org/Reports/Report16Vol1.pdf (Accessed 15 January 2013).

CHAPAGAIN AK, HOEKSTRA AY, SAVENIJE HHG and GAUTAM $\mathrm{R}$ (2006) The water footprint of cotton consumption: An assessment of the impact of worldwide consumption of cotton products on the water resources in the cotton producing countries. Ecol. Econ. 60 (1) 186-203.

CRAMER LA (2001) The extractive metallurgy of South Africa's platinum ores. JOM 53 (10) 14-18.

CRUNDWELL F, MOATS M, RAMACHANDRAN V, ROBINSON T and DAVENPOORT WG (2011) Extractive Metallurgy of Nickel, Cobalt and Platinum-Group Metals. Elsevier, Oxford, UK. 411-435 pp.

DWAF (DEPARTMENT OF WATER AFFAIRS and FORESTRY) (1985) Evaporation and precipitation records; monthly data up to September 1980. Hydrological Information Publication No 13. DWAF, Pretoria. 43 pp.

DWAF (DEPARTMENT OF WATER AFFAIRS and FORESTRY) (2005) Drinking Water Quality Management Guide for Water Services Authorities. URL: http://www.dwaf.gov.za/Documents/ Other/DWQM/DWQMWSAGuideSept05.pdf (Accessed 5 May 2013).

DWAF (DEPARTMENT OF WATER AFFAIRS and FORESTRY) (2013) Resource water quality data for Crocodile West and Marico
WMA. URL: http://www.dwaf.gov.za/iwqs/wms/data/WMA03_ reg_WMS_boreh.htm (Accessed 1 May 2013).

GLAISTER BJ and MUDD GM (2010) The environmental cost of platinum-PGM mining and sustainability: Is the glass half-full or half-empty? Miner. Eng. 23 (5) 438-450.

HAGGARD EL SHERIDAN CM and HARDING KG (2013) Water footprint for a South African platinum mine. In Proceedings of the Water in Mining Conference, 26-28 November 2013, Brisbane, Australia.

HARDING KG (2013) A technique for reporting life cycle impact assessment (LCIA) results. Ecol. Ind. 34 1-6.

HOEKSTRA AY, CHAPAGAIN AK, ALDAYA MM and MEKONNEN MM (2011) The water footprint assessment manual: Setting the global standard. URL: http://www.waterfootprint.org/?page=files/ WaterFootprintAssessmentManual (Accessed 10 October 2012).

HOEKSTRA AY and HUNG PQ (2002) Virtual water trade: A quantification of virtual water flows between nations in relation to international crop trade. URL: http://www.waterfootprint.org/Reports/ Report11.pdf (Accessed 17 January 2013).

HOEKSTRA AY and MEKONNEN MM (2011) Global water scarcity: The monthly blue water footprint compared to blue water availability for the world's major river basins. URL: http://www.waterfootprint.org/Reports/Report53-GlobalBlueWaterScarcity.pdf (Accessed 11 September 2013).

LIDELL KS, MCRAE LB and DUNNE RC, (1986) Process routes for beneficiation of noble metals from Merensky and UG2 ores, Mintek Review 4 33-44.

MARRIS AC, WOODFIELD I and MURRAY CJ (Aqua Guardian Group) (2011) Floating module for water storage evaporation control. International Patent Application PCT/AU2010/000778.

OSMAN A, CRUNDWELL FK, HARDING KG, SHERIDAN CM, and DU TOIT A (2013) Water accountability and efficiency at a base metals refinery. In Proceedings of the Water in Mining Conference, 26-28 November 2013, Brisbane, Australia.

RANCHOD N, SHERIDAN C, PLINT N, SLATER K and HARDING $\mathrm{K}$ (2015) Assessing the blue-water footprint of an open cast platinum mine in South Africa. Water SA 41 (2) 287-293.

STATS SA (STATISTICS SOUTH AFRICA) (2000) Natural resource accounts: Updated water accounts for South Africa: 2000. URL: http:/www.statssa.gov.za/publications/D0405/D04052000.pdf (Accessed 25 February 2013).

STATS SA (STATISTICS SOUTH AFRICA) (2012) Electricity, gas and water supply industry, 2010. URL: http://www.statssa.gov.za/publications2/Report-41-01-02/Report-41-01-022010.pdf (Accessed 8 January 2014)

TATA (2013) Tata industrial water footprint assessment: Results and learning. URL: http://www.waterfootprint.org/Reports/WFN\%20 2013.Tata\%20Industrial\%20Water\%20Footprint\%20Assessment. pdf (Accessed 26 July 2013). 